\title{
Investigation of water quality in wet and dry seasons under climate change
}

\author{
J. Safieh"1, D. Rebwar ${ }^{2}$, M. H. Hamed ${ }^{2}$, M. A. H. Saeed ${ }^{2}$, J. Forough ${ }^{1}$ \\ ${ }^{1}$ Water Resource Engineering, University of Birmingham, Edgbaston St., B152TT, UK \\ ${ }^{2}$ Department of Geology, College of Science, University of Salahaddin - Erbil, Iraq \\ Corresponding author E-mail: masoud.hamed@su.edu.krd,mariwan.hamahsaeed@su.edu.krd. \\ rebwar.dara@knowledge.ed.u.krd,foroughjafary@yahoo.com
}

Received: 28.09.2020. Accepted: 28.10.2020

\begin{abstract}
Background: Providing fresh water suitable for drinking and farming and living organisms in the ecosystem is essential. To evaluate water quality, qualitative indicators are often employed for managing water resources and water quality protection and pollution abatement.

Aim: This study evaluated the quality of Borkhar basin water resources using three different water quality indices, including National Institutes of Health Water Quality Index (NIHWQI) having nine parameters, the Oregon Water Quality Index (OWQI) having eight parameters, and the Canadian Water Quality Indices (CWQI) with 22 main parameters.

Material and methods: Using data for a period of 30 years, NIHWQI, OWQI and CWQI were used. To analyze water quality of the entire basin for current and future time

New findings: Results showed that water quality of the basin was in a very moderate range according to NSFWQI, and was in a very bad range accordingly to OWQI. Water quality forecasts showed that future water quality would be bad, based on OWQI and moderate based on NSFWQI, whereas based on CWQI, it will be good for drinking, and bad for aquatic animals, recreation, irrigation, and livestock use.
\end{abstract}

Keywords: Quality Indicators; NSFWQI; OWQI; CWQI; Borkhar basin

\section{Introduction}

These days' pollution and quality of water resources in developing countries have taken on an added significance (Wan et al. 2016 and Lu et al. 2015). Population growth and increased urban, industrial, and agricultural activities are polluting surface and groundwater resources (Merrill et al., 2018). The quality of water in aquatic ecosystems (Keiser et al. 2018) and the identification of contaminated sites and contaminants for various uses are determined by physical, chemical, and physical parameters (Sicard et al.2018 and Geissen et al. 2015).

\section{The effect of climate change on water quality in Middle East}

Climate alteration in Middle East is one significant element that is recognized to affect water supplies and ecosystems. The key impact of climate alteration on water quality is assigned to altering air temperature and hydrology. Water temperature in Middle East is directly influenced through ambient air temperature and is anticipated to rise in consequence of global warming. Differences in water temperature can effect on physico-chemical parameters (e.g., nitrification, mineralization of organic matter, etc.) in rivers and next alter transport and concentration of contaminants. Rises in water temperature in Middle East consequence in decreased oxygen solubility therefore decreasing dissolved oxygen (DO) concentrations and DO concentrations at which saturations happens. Decreased DO concentrations will have an impact on the duration and intensity of algal blooms which significantly found in Middle East areas such as Iran, Saudi Arabia, Egypt and Syria. Water pollution can decrease dissolved oxygen (DO) concentrations. Decreased DO concentrations in Middle East areas will have an effect on the period and intensity of algal blooms. Climate alteration is supposed to alter the availability, seasonality and changeability of flow in rivers. These hydrological effects of climate alteration can particularly influence on water quality of basins in Middle East areas. There is a few studies that worked on estimation of water quality under climate change effects. However previous indicated that low flow events because of climate alteration would be of a bigger concern than high flow events in this district. Various studies emphasized that higher water temperatures and lower flow rates throughout summer may cause deficiency to water quality in basins . For instance, a review by Bucak et al. (2018) indicated how lower flow in summer can cause rises in phosphorus concentrations and biological oxygen demand (BOD) and decline in DO concentrations in rivers which, in opportunity, may cause enhanced algal growth in Turkey. Under decreased flow in summer, ammonium concentrations decline because of a rise in the nitrification rate with resulting rise in nitrate concentrations. Another study in Syria analyzed the water quality (nutrient and dissolved oxygen concentrations) and understand that because of raised air temperature resulting from climate alteration and increased flows to meet future water demand, so water pollution is increased. The most factors of water quality which affected by climate change is analyzed by Noorka et al. (2015) and shows in Table 1. 
Table 1. The most factors of water quality which affected by climate change.

Major impacted components

Water temperature

Water salinity

Pollutant concentrations
Some potential effects

Changes in chemical quality

Changes in biological quality

Changes in thermal quality

Fauna and flora

One of the simplest methods is statistical, based on indicators, that can reflect the qualitative conditions of water, for water quality management (Wu et al. 2018andLi et al. 2016). The indices, based on reducing the primary raw data plus the expression of water quality, indicate the trend of water quality changes over time and time (Jonah et al. 2015 and Malsy et al. 2017). Previous studies analyzed trends of water quality changes using different methods. Hariyanto et al. (2018) conducted a survey on the Porong River, and found that the status of river water quality was in the middle class. Al-Adamat (2017) conducted a survey of surface water quality for pollution risk using NSFWQI and WRASTIC. He showed that water quality at a river station was only in the middle range and that at other stations was undesirable in all seasons. Das et al. (2018) investigated the quality of drinking water in the Upper Odeesh and Oudisha area in India and showed that water was not suitable for drinking and was not at an acceptable level, and that the water in this area after treatment could be suitable for drinking. Gissiet al. (2016) surveyed river water quality in eastern Asia and showed that water quality of rivers was in different classes. Pati et al. (2018) showed that in the Rushikulya River basin BOD, TS, and EC parameters of turbidity, nitrate, phosphate, and fecal coliform at the entrance of river into the plain and at the intersection agricultural waste and residential centers with the Rushikulya River had been significantly altered and had a significant increase at the first station. Geng (2017) surveyed river in China, and the calculated OWQI showed very poor quality of that river during the survey period. Suratman et al. (2015) examined the water quality of a river in Malaysia using a special water quality index and showed that agricultural activities and livestock farms around the river whose sewage entered the river led to a decrease in water quality. An investigation by Dharmendra et al. (2018) and Mohapatra et al. (2016) on the Atarabanki River and the Taladata canal in the Indian Paradipia region indicated that river water quality deteriorated due to industrialization and human activities. Ding et al. (2016) investigated the quality of water in a river in China, and showed that the river water was not suitable for local use and should be treated. Ullah et al. (2017) reviewed the quality of river water in different countries. With the use of quality indicators, it is possible to identify areas that are threatened by pollution and manage water resources (Duan et al. 2016 and Zhang et al.2017). There are two groups of indicators, contamination indices that increase with the increase in the number of indexes(BCWQI) and quality indicators that decrease their indexes with increasing pollution and are called qualitative indicators, as for example, NSFWQI, OWQI and CQWI.A brief explanation of these three indices is given below:

NSFWQI: Based on a survey of a large number of specialists with different specializations in the field, NSFWQI is a qualitative reduction indicator (Effendi et al. 2015). . Initially, 35 contaminants were analyzed but then9 parameters were selected for formulating the main index. These nine parameters were temperature, dissolved oxygen, biochemical oxygen demand, acidity, nitrate, total phosphorus, total soluble solids, fecal coliform, and turbidity.

OWQI: The Oregon Water Quality Index was formulated by an Environmental Quality Issues Survey Group in 1979 (Krishan et a1. 2016). This index is an indicator of water use classification and is mostly used to evaluate the quality of water for recreational purposes. The simplicity and availability of required quality parameters ( 8 parameters) and the determination of sub-indices by means of diagrams or analytical relationships are the advantages of this index.

CQWI: The CQWI was developed by the British Columbia Environment in 1990 and is one of the important indicators for assessing surface water for the conservation of aquatic life and water use. This index, considering the required physical and biological parameters, qualitatively considers water resources for drinking, farming, aquaculture, recreation, and livestock uses (Gitau et al. 2016). In this index there is no parameter limit and the more the parameters are the more accurate the evaluation will be (Krishan et al. 2016). A number of studies have used the above indices to evaluate the quality of water resources. For example, NSFWQI was used to assess the Anzali wetland water quality using data from 10 stations in 2017, which indicated the average quality of wetland water (Fallah et al. 2017).The water quality of Karkheh Reservoir Lake was evaluated by different indices and NSFWQI was recommended as a suitable indicator. To assess the water quality of rivers in Iran, these indices have also been used for Jajrood River, Zohreh River, Murad Beik River in Hamedan and Karun and Dez River. In this study, NSFWQI, OWQI, and CQWI were used to evaluate the spatial and temporal changes in the quality of Borkhar basin water resources for drinking, aquaculture, and agriculture (Misaghi et al. 2017; Mohseni et al. 2015; Hoseinzadeh et al. 2015; Noori et al. 2019; Aazami et al. 2015; Alexakis et al. 2015and Bhutiani et al. 2016).

\section{Materials and Methods}

In this section, the study area is explained first section and then the calculation and simulation of water quality indices and the necessary data are explained section In section a new climate change model is analyzed in order to investigate future wet and dry seasons and then analyze future water quality during these seasons. 


\section{Study area}

The Isfahan-Borkhar plain is situated in the Isfahan province, Iran, as shown in Figure 1 . The plain is located between $51^{\circ} 05^{\prime}$ and $51^{\circ} 58^{\prime}$ longitude and $32^{\circ} 33^{\prime}$ and $33^{\circ} 16^{\prime}$ latitude and its area is approximately $1643 \mathrm{~km}^{2}$. The elevation of the plain varies from 1731to $1554 \mathrm{~m}$ above the mean sea level. The Zayandeh-Rud River is a major river in the basin, which crosses through the south of this plain. The average temperature is approximately $16^{\circ} \mathrm{C}$. The coldest month is January and the warmest month is March. The mean annual precipitation is approximately $115 \mathrm{~mm}$. The average annual potential evapotranspiration is approximately $2400 \mathrm{~mm}$ (Figure 1). The unconfined aquifer of Isfahan-Borkhar basin is located in the Isfahan province (Marani-Barzani et al., 2018). Based on the structure-sedimental zoning of Iran, the Isfahan-Borkhar basin is located in the Sanandaj-Sirjan sub-zone in the central region of Iran. About $64 \%$ of this area $\left(2405 \mathrm{~km}^{2}\right)$ contains alluvial plains and the remainder $36 \%\left(1367 \mathrm{~km}^{2}\right)$ is approximately rocky outcrops. The lithology of the rocky outcrops contains a sequence of sedimentary foundations which include permeable rocks like limestone and dolomites (e.g., Klsol, OMql, and Pj units), impermeable to low permeability rocks, such as shale and marl (e.g. Kdzsh, Ksml, and Mur units), and also sandstone and conglomerate rocks (e.g. TRn and K1c units). Quaternary alluvium contains soft alluvial zones and flood plain deposits comprising fine-grained soils (Qal). Figure 2 displays the geological map of the IsfahanBorkhar basin (Marani-Barzani et al., 2018).

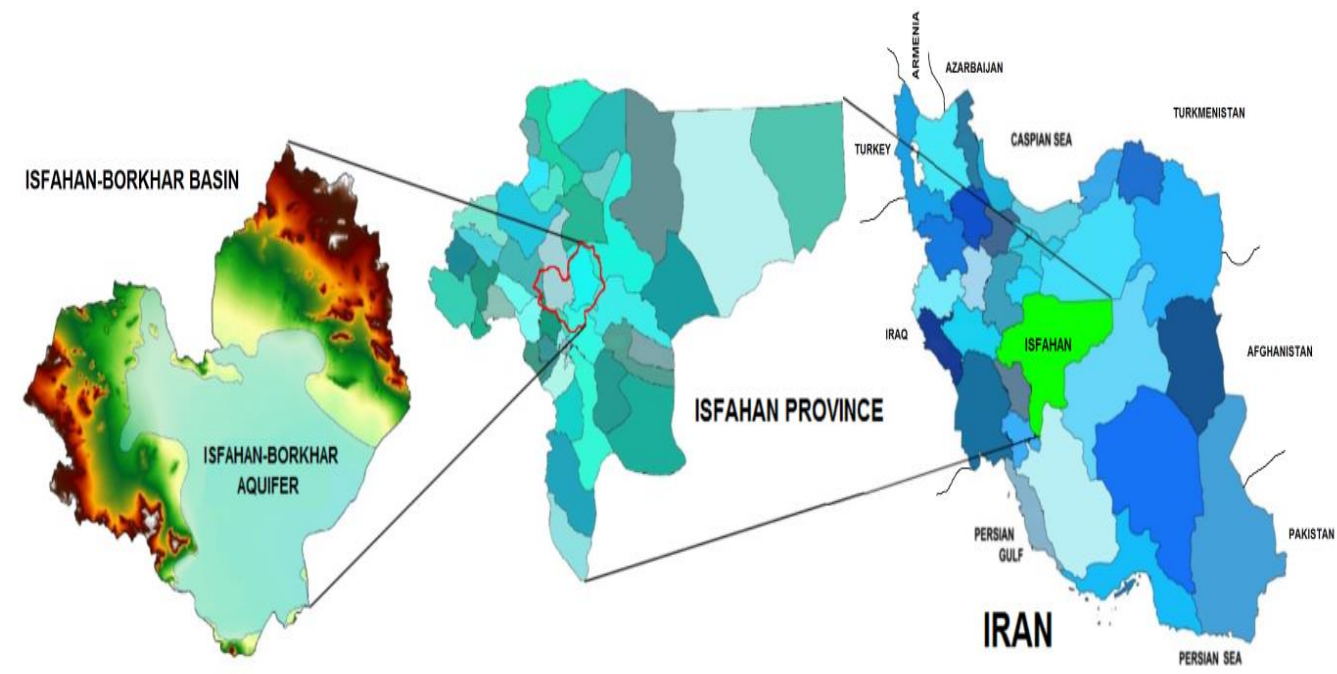

Figure 1. Location of the study area.

\section{Methodology}

The parameters required for obtaining the values of qualitative indices in the selected months are given in Table 1 . For each station, concentrations of parameters were sampled over several months, and for selected months, the monthly mean concentrations of parameters measured on the surface, at depth, and at basin flood margins were considered. OWQI and NSFWQI were obtained using the concentrations of parameters at several stations and the average values for several months. In this index, each parameter was assigned a weight or numerical value to determine its effect, as shown in Table 1 . The highest and lowest weights, respectively, were related to the concentrations of dissolved oxygen in water and total solids concentration. Water quality was classified according to NSFWQI, which varied from zero to 100, and was obtained using Eq. 1 (Abba et al. 2015).

NSFWQI $=\sum_{\mathrm{i}=1}^{\mathrm{n}} \mathrm{wli}$

Eq. 1

Table 2. Water quality classifications based on index values of NSFWQI, OWQI, and CWQI.

\begin{tabular}{llll}
\hline NSFWQI & OWQI & CWQI & $\begin{array}{l}\text { Water } \\
\text { quality } \\
\text { Very low }\end{array}$ \\
0 to 25 & 0 to 60 & 0 to 44 & Low \\
26 to 50 & 61 to 79 & 45 to 64 & Ledium \\
51 to 70 & 80 to 84 & 65 to 79 & Medium \\
71 to 90 & 85 to 89 & 80 to 94 & High \\
91 to 100 & 90 to 100 & 95 to 100 & Very high \\
\hline
\end{tabular}

where $\mathrm{n}$ denotes the number of parameters and Ii below parameter $\mathrm{i}$, and wIi is the weighting factor of parameter I The charts provided by the National Institutes of Health are available to get sub-indicators. Each of the eight parameters (temperature, dissolved oxygen, biochemical oxygen demand, acidity, nitrogen, total phosphorus, total soluble solids, and fecal Coliform) was unweighted and had the same effect in the final values of the index (Talalaj et al. 2016). The same effect of the parameters with the low value and high value on the final value of the index are the major drawbacks of this index. The description of water quality was based on the numerical values of the water quality index explained above. NSFWQI varied from zero to 100, and is classified in Table 2. OWQI was given by Eq. 2 (Kachroud et al. 2019):

$$
\mathrm{OWQI}=\sqrt{\frac{\mathrm{n}}{\sum_{\mathrm{i}=1}^{\mathrm{n}} \frac{1}{\mathrm{SI} 2}}}
$$

where $\mathrm{n}$ is the number of parameters, and SI is the parameter I. OWQI was calculated using the multi-month data of Table 4. In order to increase the accuracy of index, the data of the main components and Table 3 were calculated using a software, WHO. The software evaluated the concentrations of 22 different parameters and were compared with the standard values (Jha et al. 2015 and 
Kafrawy et al. 2017). Sampling at least four times and four parameters were needed to use this index. In the calculation of this index, there was no parameter limitation, and the more the number of parameters, the more the accuracy of evaluation. A general relation was obtained as formula Eq. 3 (Chirgwin et al. 2018):

$\mathrm{CWQI}=100-\left[\sqrt{\mathrm{F} 1^{2}}+\mathrm{F} 2^{2}+\mathrm{F} 3^{2}\right] / 1.732$

Eq. 3

Table 3. Value of CWQI in the basin.

\begin{tabular}{|c|c|c|c|c|c|c|c|c|c|c|c|c|c|}
\hline $\begin{array}{l}\text { Param } \\
\text { eter }\end{array}$ & $\begin{array}{l}\text { Sodiu } \\
\text { m(ppm } \\
\text { ) }\end{array}$ & $\begin{array}{l}\text { Pot } \\
\text { assi } \\
\text { um } \\
\text { (pp } \\
\text { m) }\end{array}$ & $\begin{array}{l}\text { Magn } \\
\text { esium } \\
\text { (ppm) }\end{array}$ & $\begin{array}{l}\text { ZN } \\
(p p \\
m)\end{array}$ & $\begin{array}{l}\text { Plumb } \\
\text { um(p } \\
\text { pm) }\end{array}$ & $\begin{array}{l}\text { Mercu } \\
\text { ry(pp } \\
\text { m) }\end{array}$ & $\begin{array}{l}\text { Cru } \\
\text { m(p } \\
\text { pm) }\end{array}$ & $\begin{array}{l}\text { Cadmiu } \\
\text { m(ppm } \\
\text { ) }\end{array}$ & $\begin{array}{l}\text { Arse } \\
\text { nic( } \\
\text { ppm } \\
\text { ) }\end{array}$ & $\begin{array}{l}\text { Alumin } \\
\text { um(pp } \\
\mathrm{m})\end{array}$ & $\mathbf{P H}$ & $\begin{array}{l}\text { hyd } \\
\text { raul } \\
\text { ic } \\
\text { con } \\
\text { trol }\end{array}$ & $\begin{array}{l}\text { Temp } \\
\text { eratu } \\
\text { re (C) }\end{array}$ \\
\hline Value & 33.12 & 3.14 & 22.63 & $\begin{array}{l}51.2 \\
5\end{array}$ & 0.02 & N.D & $\begin{array}{l}0.00 \\
2\end{array}$ & N.D & N.D & 0.14 & $\begin{array}{l}9.0 \\
9\end{array}$ & $\begin{array}{l}46.1 \\
2\end{array}$ & 17.5 \\
\hline
\end{tabular}

Table 4. Water quality values based on NSFWQI and OWQI and CWQI.

\begin{tabular}{|c|c|c|c|c|c|c|c|}
\hline Parameter/station & Station 1 & Station 2 & Station 3 & Station 4 & Station 5 & Station 6 & Station 7 \\
\hline Temperature & 20 & 22.18 & 20.93 & 20.7 & 21.33 & 21.63 & 20.7 \\
\hline Turbidity (NTU) & 1 & 1.19 & 1.20 & 4.34 & 1.90 & 1.94 & 3.02 \\
\hline Total solids(mg/l) & 187.29 & 187.23 & 188.42 & 123.64 & 184.82 & 185.55 & 174.02 \\
\hline Acidity & 8.93 & 8.97 & 8.84 & 9.59 & 8.85 & 7.87 & 7.67 \\
\hline $\begin{array}{l}\text { Total } \\
\text { Phosphate(mg/l) }\end{array}$ & 0.53 & 0.47 & 0.46 & 0.57 & 0.45 & 0.52 & 0.50 \\
\hline Nitrate $(\mathrm{mg} / \mathrm{l})$ & 0.91 & 0.61 & 0.91 & 0.61 & 0.41 & 0.31 & 0.61 \\
\hline $\begin{array}{l}\text { Nitrate and } \\
\text { Ammoniac }(\mathrm{mg} / \mathrm{l})\end{array}$ & 0.92 & 0.52 & 0.92 & 0.69 & 0.42 & 0.32 & 0.62 \\
\hline Dissolved oxygen & 90.22 & 90.22 & 87.94 & 83.55 & 81.55 & 84.67 & 67.96 \\
\hline $\begin{array}{l}\text { Biochemical oxygen } \\
\text { demand }\end{array}$ & 7.46 & 6.34 & 7.27 & 7.55 & 7.31 & 7.37 & 8.28 \\
\hline Fecal Coliform & 67.50 & 20.70 & 8.60 & 63.62 & 100 & 150.80 & 125.50 \\
\hline NSFWQI & 71 & 73 & 73 & 67 & 69 & 68 & 60 \\
\hline OWQI & 48.16 & 46.12 & 47.54 & 46.38 & 45.66 & 44.84 & 38.12 \\
\hline
\end{tabular}

Table 5. Water quality analysis based on CQWI.

\begin{tabular}{lllllll}
\hline & Total & Drinking & Aquatic & Entertainment & Agriculture & Livestock \\
F1 & 22 & 18 & 45 & 0 & 0 & 0 \\
F2 & 23 & 26 & 39 & 0 & 0 & 0 \\
F3 & 55 & 16 & 67 & 0 & 0 & 0 \\
CWQI & 60 & 82 & 50 & 101 & 101 & 101 \\
Category & low quality & high quality & low quality & very high quality & very high quality & very high quality \\
\hline
\end{tabular}

Table 6. Water quality values based on NSFWQI and OWQI and CWQI for future time period.

\begin{tabular}{|c|c|c|c|c|c|c|c|}
\hline Parameter/station & Station 1 & Station 2 & Station 3 & Station 4 & Station 5 & Station 6 & Station 7 \\
\hline Temperature & 21.5 & 23.68 & 22.43 & 22.2 & 22.83 & 23.13 & 22.2 \\
\hline Turbidity (NTU) & 1.5 & 1.69 & 1.7 & 5.84 & 2.4 & 2.44 & 3.52 \\
\hline Total solids(mg/l) & 187.59 & 187.53 & 188.72 & 123.94 & 185.12 & 185.85 & 174.32 \\
\hline Acidity & 8.94 & 8.98 & 8.85 & 9.6 & 8.85 & 7.87 & 7.68 \\
\hline Total & 1.01 & 0.95 & 0.94 & 1.05 & 0.93 & 1 & 0.98 \\
\hline \multicolumn{8}{|l|}{ Phosphate(mg/l) } \\
\hline Nitrate (mg/l) & 1.41 & 1.11 & 1.41 & 1.11 & 0.91 & 0.81 & 1.11 \\
\hline Nitrate & 1.42 & 1.02 & 1.42 & 1.19 & 0.92 & 0.82 & 1.12 \\
\hline \multicolumn{8}{|l|}{ Ammoniac $(\mathrm{mg} / \mathrm{l})$} \\
\hline Dissolved oxygen & 89.72 & 89.70 & 87.44 & 83.05 & 81.05 & 84.17 & 67.46 \\
\hline $\begin{array}{l}\text { Biochemical oxygen } \\
\text { demand }\end{array}$ & 6.96 & 5.84 & 6.77 & 7.05 & 6.81 & 6.87 & 7.78 \\
\hline Fecal Coliform & 67.92 & 21.12 & 9.02 & 64.04 & 100.42 & 151.22 & 125.92 \\
\hline NSFWQI & 67 & 70 & 71 & 65 & 67 & 66 & 58 \\
\hline OWQI & 47.84 & 45.8 & 47.22 & 46.06 & 45.34 & 44.52 & 37.8 \\
\hline
\end{tabular}

where the F1 factor was obtained by dividing parameters that were more than standard over all measured parameters in the sampling period and expressed as a percentage. The frequency factor $\mathrm{F} 2$ was divided by the number of times the total of parameter measurements exceeded the standard, and was expressed as a percentage, and factor F3 was the value obtained by using Equation 
4. First, the parameter concentrations were determined at one specific time (the standard value was greater than the standard parameter value), so the target was divided, and from that one unit would be reduced to a degree of defeat. Then, by calculating the mean of the normalized violation, which was obtained by dividing the total sum of violations and the magnitude of the excited load, F3 was calculated using Eq. 4.

$\mathrm{F} 3=\frac{\mathrm{nse}}{0.01 \mathrm{nse}+0.01}$ Eq. 4

The qualitative water classification was based on the numerical values of CWQI, which varied from zero to 100 , as given in Table 2.

\section{Climate change models}

Normally, climate alteration predictions organized via models are not associated with the 'real' natural environment because of suspicions and data errors in the models. The recently CMIP5 consequences concentrate on fill this gap with a improved resolution for the models and also with novel climate alteration scenarios. In this paper, various productions from climate models applying monthly output from $39 \mathrm{GCM}$ which participated in the CMIP5 were applied. The innovative models are more varied and more improved contrasted to the CMIP3. Additionally, the CMIP5, innovative models for forecasting climate alteration applying various scenarios, like "Representative Concentration Pathways" (RCP) were developed through Van Vuuren et al. (2011). This model could be used in order to anticipate the GHG alleviation potential. Model scenarios which were applied in this study contained historical simulations and future forecasts. The historical models were through observed natural and anthropogenic atmospheric composition alterations spanning 1971-2005; they utilized in order to generate a baseline against which to determine climate alteration in future forecasts. The future forecast achieved via forcing from the RCPs. Contrasting the Special Report on Emission Scenarios (SRES) that announced the climate forecasts for the previous CMIP experiment (CMIP3), the $\mathrm{CO}_{2}$ attentiveness in RCP2.6 is lower than B1, in RCP6.0 is a little higher than in A1B, and in RCP8.5 it exceeds A2. In this paper, all the RCP scenarios applied for 2006-2044. However, the severest potential GHG path (RCP 8.5) for the 21st century may make the strongest planning adaptation to decrease the potential climate alteration effects on water supplies. Many ensemble members are available for each CMIP5 scenario for the specified model. Assuming that there are adequate models in the ensemble to organize a reliable evaluation of a potential climate alteration signal, only one ensemble from each CMIP5 model (total 38 models) and scenarios of RCPs applied in this study. The variables applied were: temperature, relative humidity, precipitation and wind speed. The aim of providing 38 coupled GCMs for the various scenario of RCPs is to characterize the hesitation in climate effects growing from future climate modelling. Additionally, biases in climate variables such as precipitation should be concentrated to; if not they will enlarge into the calculations for the following years. In order to solve the resolution difficulties and possible errors in GCM outputs, the GCM downscaled statistically to the meteorological stations separately. Nevertheless, in order to decrease the model error and rise the resolution accuracy this research used an easy downscaling technique to rise the truthfulness of the model. Various downscaling techniques attempt to improve daily timescales. In this study, because of data available, just monthly average climate data are requested and hence calculating the high-frequency variability (the intent of more compound methods) is not necessary. In order to remove bias amongst the GCM and reality, monthly precipitation and temperature time series from GCM and observations for a specific site for the related reference episode is preferred, which is signified through Xp, gcm and Xp,obs respectively. Moreover, the creation from the GCM for some future episode of the equal length as the reference episode, $\mathrm{Xf}, \mathrm{gcm}$ was required. The question appears in which way to best combine these three supplies of information into the most true projections of the unknown future observations Xf, obs to use as input for the model of water balance. This current study improved a general technique considering obviously the change factor. The change factor is similar to delta change methods applied for weather generators. Nevertheless, the method used here is easier; an equally moved and scaled version of the observed time series applied for the future rather than a series taken from a weather generator. The change factor approach used the observed monthly variability and alterations in monthly mean and variance as modelled through the GCM. In the simplest case this is the "delta method," where the monthly alteration is assumed to have the equivalent magnitude in the future and reference episodes, and the corrected monthly data is represented in Eq. (1):

$X \operatorname{DEL}(t)=X p, o b s(t)+(X f, g c m-X p, g c m) \quad$ Eq. (1)

where the time mean is signified via the bar above a symbol and the result of the bracket (Xf, $\mathrm{gcm}-\mathrm{Xp}, \mathrm{gcm}$ ) is recognized as a climate signal.

However, in a more general case, deliberating alterations in variance is revealed in Eq. (2):

$\mathrm{X}(\mathrm{f}, \mathrm{obs} \mathrm{m}, \mathrm{y})=[\overline{\mathrm{Xf}, \mathrm{gcm} \mathrm{m}]}+[\overline{\mathrm{X} \mathrm{p}, \mathrm{obs} \mathrm{m}]}]-[[\overline{\mathrm{X} \mathrm{p}, \mathrm{gcm} \mathrm{m}]} *[\overline{\overline{\sigma \mathrm{\sigma}, \mathrm{gcm} \mathrm{m}, \mathrm{gcm} \mathrm{m}}}] \mathrm{Eq} .(2)$

where $\mathrm{X}_{(\mathrm{f}, \mathrm{obs}, \mathrm{m}, \mathrm{y})}$ signifies the unknown future observation amount of variable $\mathrm{X}$ for a particular month, $\mathrm{m}$, and year, $\mathrm{y}$. The variables involve temperature, rainfall, relative humidity, and wind speed; $\mathbb{X}_{\mathrm{f}, \mathrm{gcm}_{\mathrm{m}}}$ signifies the mean future simulation for a specific month and episode of years (such as 2006 to 2044). $\mathbb{X}_{\mathrm{p}, \mathrm{obs}_{\mathrm{m}}}$ is the mean present-day observed climate for a specific month averaged through all years of the historical episode (1971-2005), as measured from the meteorological stations in the research area; $\mathrm{X}_{\mathrm{p}, \mathrm{gcm}_{\mathrm{m}}}$ represents the mean simulation from GCM for a specific site for the reference episode (e.g. 1971-2005); $\bar{\sigma}_{f, g c m_{m}}$ and $\bar{\sigma}_{p, g c m}$ denote the standard deviations of the raw model output for the future and present-day episode for a individual month. So as to select a model (among 39 models) and apply its climate data as an input to the model of hydrology and water balance, CDF method used. With the CDF method, a model with the minimum bias in the raw precipitation might be chosen. The main purpose for this selection is based on the hypothesis that GCMs with a true current climate will have a true climate alteration signal.

\section{Mann Kendal test}

In order to understand the trend of the effect of climate change on water quality the Mann Kendal test is used. This is one of the most common non-parametric methods for analyzing the hydrological and meteorological series. Various studies carried out using this method indicate that it is important in applying trend analysis to time series. This method is used to assume randomness of the data sequence against the existence of the process. The strengths of this approach can be explained by the suitability of 
applications for series that do not follow a particular distribution. The negligible influence of this method on the limit values seen in some time series is another advantage of using this method. The null hypothesis implies that there is a randomness and lack of trend in the data series, and the assumption of a reason is based on the trend in the data series. The steps to calculate the MannKendall are as follows:

Calculate the difference between each observation with each other and apply the sign function and extract the parameter $\mathrm{s}$ in equation (1).

$\mathrm{S}=\sum_{\mathrm{k}-1}^{\mathrm{n}-1} \sum_{\mathrm{k}-1}^{\mathrm{n}-1} \operatorname{sgn}(\mathrm{xj}-\mathrm{xk}) \quad$ Equation (1)

Which sgn can calculate by Equation (2):

$\operatorname{Sgn}(x)=\left\{\begin{array}{c}+1 \text { if }(x j-x k)>0 \\ 0 \text { if }(x j-x k)=0 \\ -1 \text { if }(x j-x k)<0\end{array}\right\} \quad$ Equation (2)

Calculate the variance by the equation (3):

$\operatorname{Var}(s)=(n(n-1)(2 n+5)) / 18 \quad$ Equation $(3)$

$\mathrm{T}$ and $\sigma$ which are used in Mann-kendall ca calculate by equation 4 and 5 :

$\mathrm{T}=2 \mathrm{~S} / \mathrm{N}(\mathrm{N}-1)$

Equation (4)

$\sigma=\sqrt{\frac{1}{18} \mathrm{n}(\mathrm{n}-1)(2 \mathrm{n}+5)-\sum_{\mathrm{i}=1}^{\mathrm{m}} \mathrm{t}(\mathrm{t}-1)(2 \mathrm{t}+5)}$

Equation (5)

Where $\mathrm{N}$ is the number of observational data and $\mathrm{M}$ represents the number of series in which at least one duplicate data exists and $T$ represents the frequency of the same value data and $Z$ is obtained from equation 6 :

$Z=\left\{\begin{array}{ccc}\frac{s-1}{\sqrt{\operatorname{Var}(s)}} & & s>0 \\ & 0 & \\ \frac{s+1}{\sqrt{\operatorname{Var}(s)}} & s<0 & \end{array}\right\}$

In a double-sided metric to process the data series, the null hypothesis is accepted in the following condition:

$\mathbf{Z}<\mathbf{Z a}$

Where $a$ is a significant level of the test and $Z$ is the standard distribution at the significant level $A$. In this research, we have calculated for a significant level of $95 \%$.In case of positive $z$, the trend of the data series is set to bullish if the downside is negative.

\section{Results and Discussion}

Table 2 shows the value of OWQI and NSFWQI. The biggest value of NSFWQI was 73 and belonged to stations 2 and 3 . This was due to the proper conditions of these stations in terms of concentration of coliforms and low concentration of total phosphate in comparison to other stations. Due to the city wastewater collection in recent years, station 7 had the lowest value. Due to the diversion of river into the lake and the introduction of a large amount of pollutants from the agricultural land washing around the river, it had a small NSFWQI index. In addition, the river annually entered a large amount of sediment and suspended matter into the lake, affecting its quality and increasing the opacity at station 4.Results indicated that stations 2 and 3 were in good quality and medium-range. In general, NSFWQI ranged from 60 to 73 . The basin water was located at all stations except station 7 on the good and medium quality boundary. Based on the average values of this index, it was within the range given in the table.

Based on Tables 3 and 4, stations 2 and 3 had the greatest grade for OWQI and station 7 had the lowest grade for OWQI. Due to the effect of the same parameters, the low one or two sub-indexes led to a sharp drop in the final index. Because the values of parameters were equal and the opacity was not one of the parameters, the quality at stations1, 5, and 6 was better than the quality at station 4, in contrast to NSFWQI. Table 3: Value of CWQI in the basin. The values of NSFWQI and OWQI showed that the water of lake was better in some months due to the dilution of pollutant concentration and the improvement of lake water quality due to increased weather in these months. However, NSFWQI did not show much change, but for some months it was the lowest. In general, the time variation of this indicator indicated that the lake water was in good quality range in the months of December, February, and June, and was in the medium range in other months. But according to OWQI, the lake water quality of was in a bad quality range in December and was in very bad range in other months. In areas where rainfall was higher, although the quality of some of the parameters involved in the calculation of indicators improved, the amount of phosphate and nitrate in the lake water increased due to the phosphate and nitrate fertilizer used in agricultural fields. Figure 2 and Tables 5 and 6 show the results of CWQI for the basin.

\section{Future water quality}

Mann Kendall test: The result of Mann-Kendall test for the most important water quality parameters is shown in Table 7. 
Table 7. The result of Mann-Kendall test for the most important water quality.

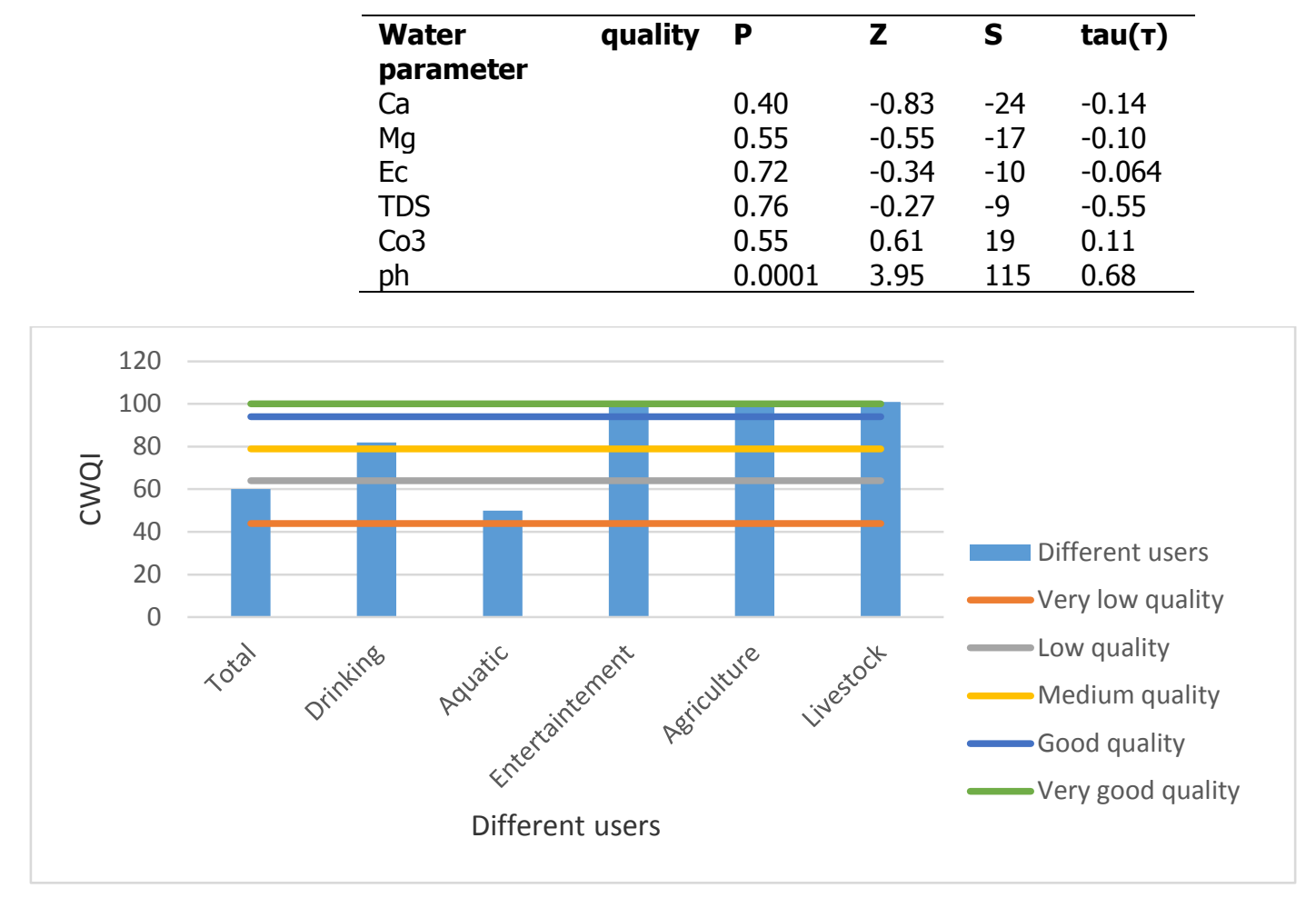

Figure 2. The value of CWQI for different water users.

Figure 3 shows the value of NSFWQI for each station. Based on future climate change and defining the future wet and dry seasons, the future water quality was calculated which is shown in table 6 and Figures 4 and 5 . Based on the quality indicators used, water quality was better in winter than in summer. The average number of indicators in cold months was better than in warm months. In summer, due to the increase in the inflow of pollutants, the amount of river pollution was higher. This result confirmed the findings of Collins et al. (2019) in the United States. The reasons for decreasing water quality during the summer season included the increase in fertilizer levels, pesticides, and chemical residues due to agricultural activity. In winter, due to cold weather, the amount of agricultural activity decreased and less wastewater entered the river. Also, high precipitation resulted in higher water quality in winter. As mentioned in preceding sections of this paper, previous research only applied one water quality index with a few quality parameters to analyze water quality conditions. For example, Wahid et al. (2018) used Canadian method (CCME) in Kirkuk region for six months in 2018.Wu et al. (2018) used WQI for one year in the Lake Taihubasin in China. Also, previous studies, such as (Kumpel et al., 2016), did not consider climate temperature which can affect water quality. In addition, there is lack of research which used future climate change model to analyze the effect of climate change during wet and dry seasons on water quality(Effendi, 2016).Also, in previous works, such as Liu et al., (2016), mapping zone of water quality was not analyzed. So this research filled this gap by modeling water quality during future climate change using multi- water quality index and climate change under a new RCP scenario. Results showed that stations 2 and 3 had better quality than the other stations, and station 4 had less quality than other stations. Also, the water quality in the upstream was better than in the downstream. This result confirmed the findings of Chen et al. (2016) in China.

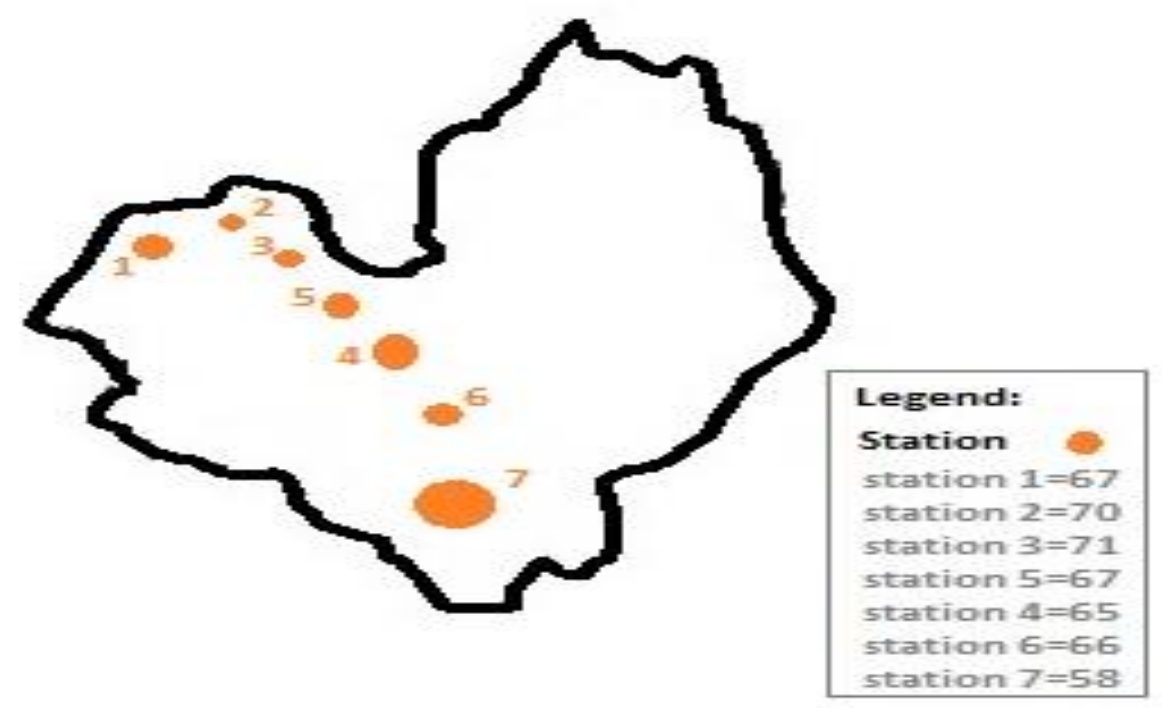

Figure 3. The value of NSFWQI for each station. 


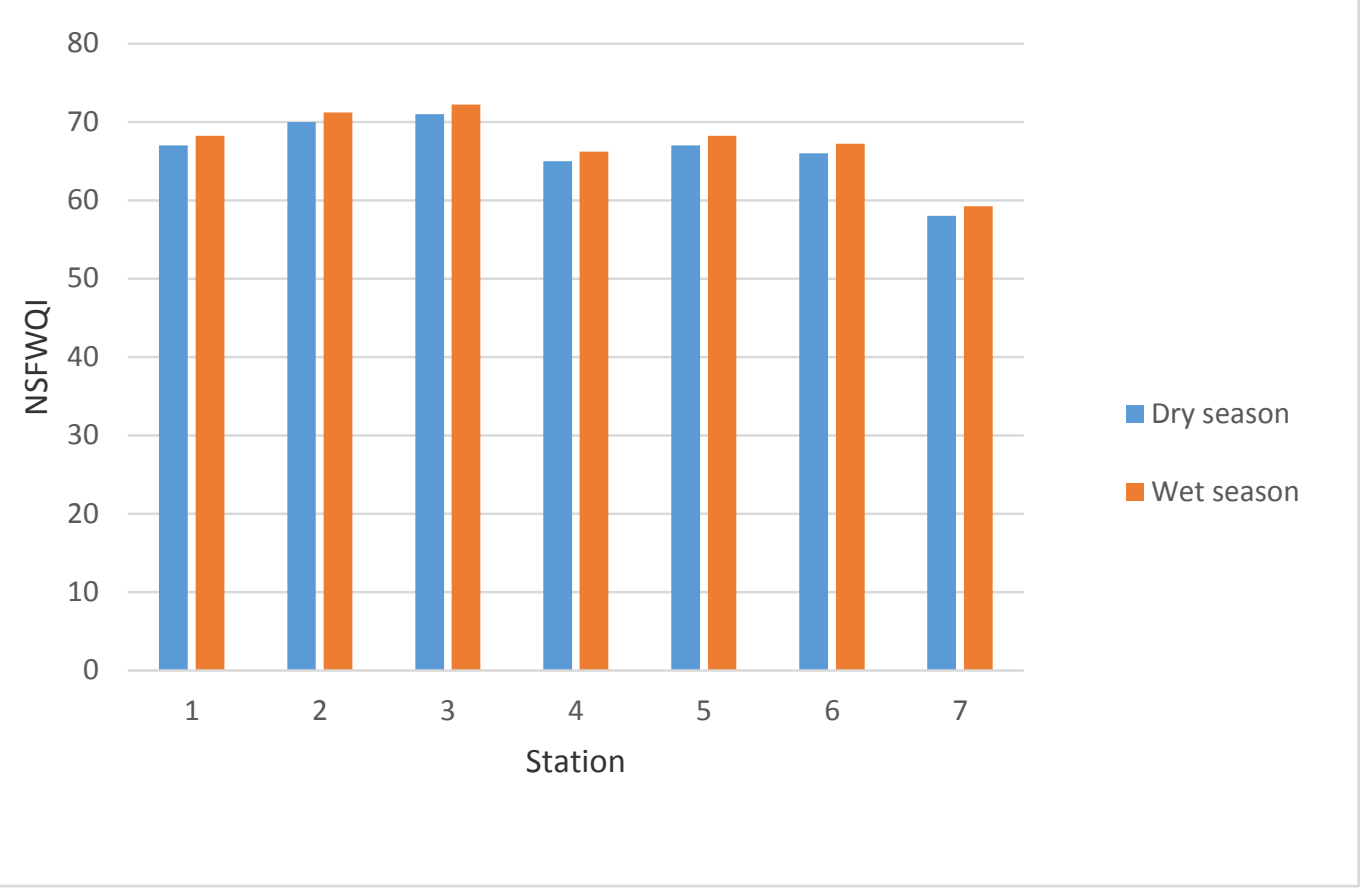

Figure 4. Value of NSFWQI for wet and dry season in future.

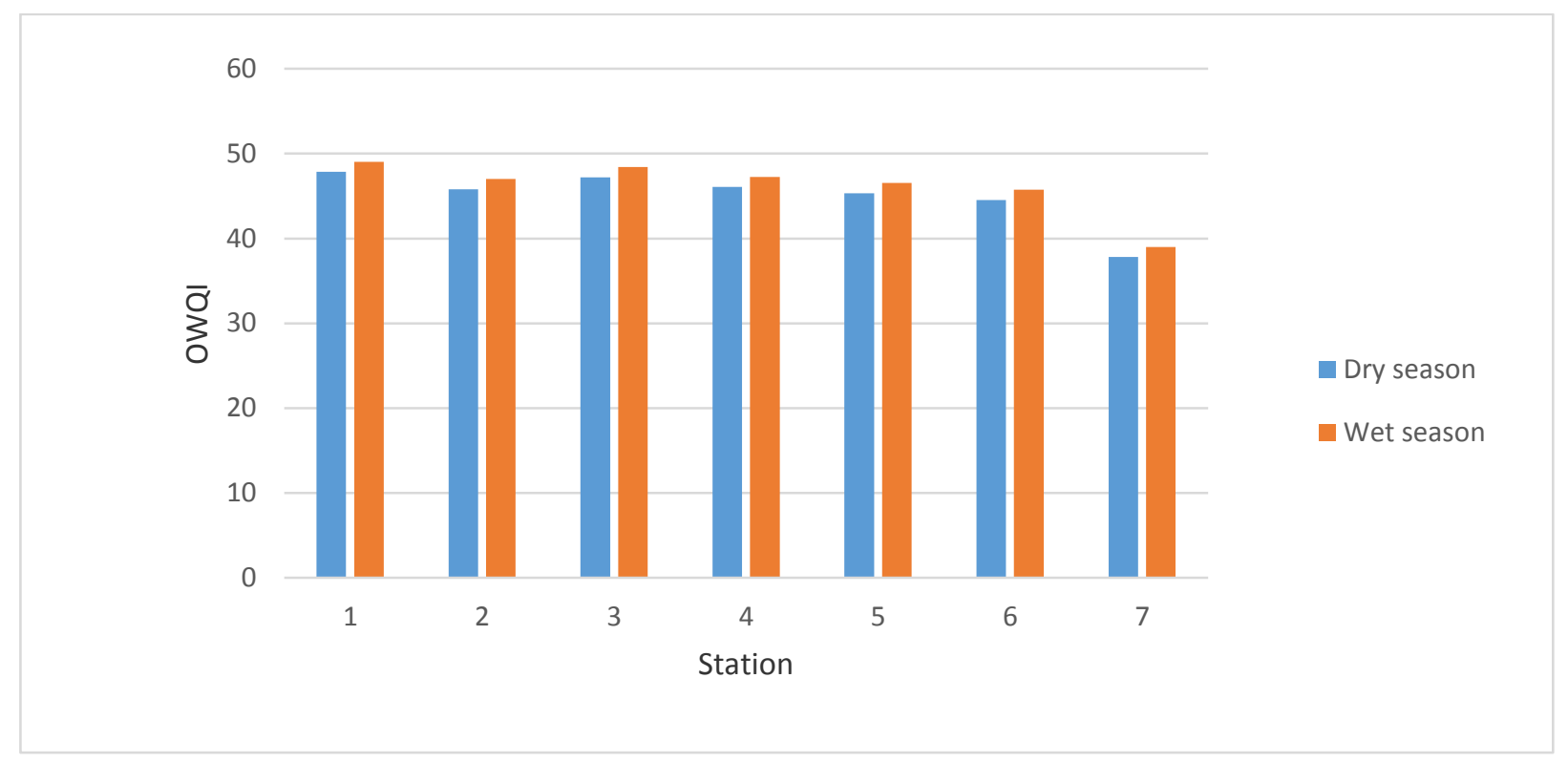

Figure 5. Value of OWQI for wet and dry season in future.

\section{Impact of increased air temperature on water quality}

Several studies mentioned that water temperature will rise as a result of global warming. Previous studies indicated such as Piccolroaz et al. (2016)that water temperature will rise among 2010 and 2080 with a confirming reduce in ice thickness because of warmer air temperatures. The uncertainty in ice cover period in their study is mainly assigned to the average flow rate applied in their models. Ice breakup is intensely influenced through when spring runoff occurs. A decrease in the concentrations of NH4-N, NO3-N, and PO4-P anticipated because of warmer water temperatures as a result of risen air temperatures as a result of global warming. The most important decrease in the nutrient concentrations forecasted throughout the open-water period in relation to the ice covered episode. A similar research by Cross et al. (2015) also indicated that nutrient concentrations in rivers decline when air temperature rises. The reductions in nutrient concentrations may be a product of augmented phytoplankton growth, such that more algae are using more nutrients, and thus a minor concentration of nutrients keeps in the water. A decreasing trend in total phosphorus concentrations in winter throughout two decades (1990-19980) was discovered through Zhang et al. in a shallow reservoir in China, which could be assigned to a rise in grazer abundance. Decreased ice cover period and ice thickness as presented in the study of Pollard et al. (2015) because of act favorably towards phytoplankton growth as a result of better light conditions in winter. Dissolved oxygen concentrations also anticipated in their study to decline in all months, except in January when DO concentrations were predicted to rise a little. Hutchins et al. (2018) also predicted a decrease in DO concentrations in the River Thames by the 2080 as a result of decreased saturation concentrations of DO and augmented biological oxygen request. In contradiction of rivers, some climate alteration studies on the water quality of lakes represent that greater water temperatures and 
rises in oxygen request encourage the release of nutrients from sediments subsequent in more nutrient enrichment of the water column. For example Qu'Appelle River is shallow, therefore the anoxic circumstances which might result in remobilization of nutrients is not a major issue (Terry et al. 2018). In this current study influence of higher water temperatures on water quality of the basin would consequently affect the water quality of the river system. Such influence was not considered in this current study.

\section{Impact of increased/decreased flow on water quality}

The modelling results are established on water quality parameter concentrations predicted at Borkhar basin, at the point where nutrient concentrations and loadings are because of concentrations from Borkhar basin. In winter when flow increased to $14 \mathrm{~m}^{3} / \mathrm{s}$ from the Zayandeh Rud River Dam, the increased flow led to an increase in $\mathrm{NH}_{4}-\mathrm{N}$ and $\mathrm{NO}_{3}-\mathrm{N}$ concentrations. This likely occurs because with increased flow in the Zayandeh Rud River from the Dam relative to its base flow, the influence of $\mathrm{NO}_{3}-\mathrm{N}$ and $\mathrm{NH}_{4}-\mathrm{N}$ inputs was declined. In contrast, the concentrations of $\mathrm{PO}_{4}-\mathrm{P}$ reduced as a result of dilution. The contribution of $\mathrm{NH}_{4}-\mathrm{N}, \mathrm{NO}_{3}-\mathrm{N}_{\text {, and }}$ $\mathrm{PO}_{4}-\mathrm{P}$ loads (kg/day) from the Zayandeh Rud in wet seasons are on average about $45 \%, 38 \%$, and $73 \%$ of the loading, correspondingly. The rise in $\mathrm{NO}_{3}-\mathrm{N}$ and $\mathrm{NH}_{4}-\mathrm{N}$ concentrations in the wet seasons may also be because of greater nitrification and mineralization rates. Rises in nutrient concentrations have been mentioned in various studies as the consequence of drought in wet seasons produced through climate alteration. For instance, augmented $\mathrm{NH}_{4}-\mathrm{N}$ concentrations in a catchment in central Greece were anticipated because of a decrease in stream dilution capacity because of climate alteration. Augmented flow in the current study during wet seasons led to an increase in DO concentrations, which may be in response to the increased reaeration rate produced by the greater water velocity and flow rate. Nutrient concentrations fluctuated in winter, when flow from the Zayandeh Rud River Dam was rised from base flow to upper $6 \mathrm{~m}^{3} / \mathrm{s}$. The rise in $\mathrm{NO}_{3}-\mathrm{N}$ concentrations and the reduction in $\mathrm{NH}_{4}-\mathrm{N}$ in November-January may be because of the increase in $\mathrm{DO}$ concentrations which would cause $\mathrm{NH}_{4}-\mathrm{N}$ oxidation to $\mathrm{NO}_{3}-\mathrm{N}$. A minor decrease in DO concentrations in dry seasons may be the result of macrophyte die-off. From the results of this study, it can be inferred that biological activities play a more significant role in summer when flow is lower than in winter.

\section{Conclusion}

Investigation of future water quality considering the effect of future climate change is important for sustainable water management. Previous researchers, such as Liu (2018) and Naubi et al. (2016), analyzed water quality only for historical time period and most of the researches, based on water quality index, used only one index. Previous researches did not combine three different water quality indices and also did not estimate and forecast future water quality. In addition previous researches, such as (Clasen et al., 2015 and Zhou et al., 2017), did not consider and did not analyze future water quality for different seasons. However, this paper applied three different water quality indices and estimated future characteristics of water quality (based on water quality indices) under climate change and scenarios (based on CMIP5 climate model and RCP scenario).Also, this study assessed future water quality for various seasons. Although the basin water quality did not change much due to feeding through permanent springs of the basin, but in the months when we had more rainfall, the water quality improved. In general, the results of this study showed that water quality in the basin's aquatic core was better than at the margins. Also, the output of the basin had the lowest quality due to the impact of city pollution. According to NSFWQI, the lake water quality was from time to time in the medium to good qualitative range. However, according to OWQI, the lake water quality during the study period was in the bad to the very bad range. While CWQI indicated bad water quality for drinking, it was considered bad for bad fish, and in terms of irrigation, recreation and livestock use, it was in excellent condition. Since NSFWQI for each parameter had a certain weight, OWQI, which considered the same weight for parameters and the opacity component was not a parameter, was more suitable for the assessment of basin water quality. CWQI, which evaluated water quality for various uses according to the quality standards, was a useful indicator. A lot of contaminating materials entered the basin. Due to the lack of sewage and refinery collection systems, the waste water of the surrounding villages also flowed into the basin, which poured a lot of pollutants into the basin. Offering a suitable cultivation pattern, preventing the development and development of sewage human activities, building wastewater collection networks and networks for surrounding villages, informing and promoting the optimal consumption culture and the importance of intrinsic water value, and constructing a more sedimentary dam were needed. In the course of seasonal rivers, in particular the Zayandeh-Rud River and their annual saline layers, it was a vital factor in improving the basin water quality and achieving the goals of sustainable water resources development, which should be at the top of development plans.

\section{Future Studies}

We assessed the potential effect of raised air temperature, produced by climate alteration, and increased flow rate, because of flow regulation, on the water quality of the Zayandeh Rud River. Other elements like land use alteration, water quality degradation of the basin, and climate alteration influence on catchment nutrient loadings were not analyzed in this study. Other researches have assessed the influence of climate alteration on land use change and its consequences on nutrient loadings. Higher nitrogen and phosphorus loadings to the river could be expected because of increased precipitation caused by global warming especially from agricultural catchments. Additional studies on the Zayandeh Rud River to consider such effects on the long-term sustainability and security of this water source would be beneficial. Algal dynamics were not analyzed in this study because of the lack of sufficient measured data for validation of the model results. To simulate algal dynamics in the river system, high-frequency and continuous sampling of the basin would be essential.

\section{Conflict of Interest Statement}

There is no conflict of interest.

\section{Data Availability Statement}

Some or all data, models, or code generated or used during the study are available from the corresponding author by request.

\section{Funding Information}

Funding information is not applicable./No funding was received./ No grants were received. 


\section{References}

Aazami, J., Esmaili-Sari, A., Abdoli, A., Sohrabi, H. and Van den Brink, P.J., 2015. Monitoring and assessment of water health quality in the Tajan River, Iran using physicochemical, fish and macro invertebrates indices. Journal of Environmental Health Science and Engineering, 13(1), p.29.

Abba, S.I., Said, Y.S. and Bashir, A., 2015. Assessment of Water Quality Changes at Two Location of Yamuna River Using the National Sanitation Foundation of Water Quality (NSFWQI). Journal of Civil Engineering and Environmental Technology, 2(8), pp.730-33.

Alexakis, D., Tsihrintzis, V.A., Tsakiris, G. and Gikas, G.D., 2016. Suitability of water quality indices for application in lakes in the Mediterranean. Water resources management, 30(5), pp.1621-1633.

Al-Adamat, R., 2017. Modelling Surface Water Susceptibility to Pollution Using GIS. Journal of Geographic Information System, 9(03), p.293.

Bhutiani, R., Khanna, D.R., Kulkarni, D.B. and Ruhela, M., 2016. Assessment of Ganga river ecosystem at Haridwar, Uttarakhand, India with reference to water quality indices. Applied Water Science, 6(2), pp.107-113.

Bucak, T., Trolle, D., Tavşanoğlu, Ü.N., Çakıroğlu, A.İ., Özen, A., Jeppesen, E. and Beklioğlu, M., 2018. Modeling the effects of climatic and land use changes on phytoplankton and water quality of the largest Turkish freshwater lake: Lake Beyşehir. Science of the total environment, 621, pp.802-816.

Chen, X., Zhou, W., Pickett, S.T., Li, W., Han, L. and Ren, Y., 2016. Diatoms are better indicators of urban stream conditions: a case study in Beijing, China. Ecological Indicators, 60, pp.265-274.

Chirgwin, W. and Maheshwari, B.L., 2018. Evaluating the suitability of water quality indices for the health of urban waterways: a case study of the Parramatta River. Water e-journal, 3(1).

Clasen, T.F., Alexander, K.T., Sinclair, D., Boisson, S., Peletz, R., Chang, H.H., Majorin, F. and Cairn cross, S., 2015. Interventions to improve water quality for preventing diarrhoea. Cochrane database of systematic reviews, (10).

Cross, W.F., Hood, J.M., Benstead, J.P., Huryn, A.D. and Nelson, D., 2015. Interactions between temperature and nutrients across levels of ecological organization. Global change biology, 21(3), pp.1025-1040.

Collins, S.M., Yuan, S., Tan, P.N., Oliver, S.K., Lapierre, J.F., Cheruvelil, K.S., Fergus, C.E., Skaff, N.K., Stachelek, J., Wagner, T. and Soranno, P.A., 2019. Winter Precipitation and Summer Temperature Predict Lake Water Quality at Macro scales. Water Resources Research.

Das, M., Nayak, A.K., Das, B. and Verma, O.P., 2018. Groundwater quality assessment and mapping using multivariate statistics and analytic hierarchy process in Bhubaneswar city, Odisha, India. International Journal of Water, 12(3), pp.195-207.

Dharmendra, S., Kumar, M.R., Chinmayee, A., Ranjan, S.D. and Ranjan, P.C., 2018. Appraisal of Temporal Variation of Water Quality Status in terms of Water Quality Index (WQI) at Paradip Port, India. Research Journal of Chemistry and Environment, Vol, 22, p.12.

Ding, J., Jiang, Y., Liu, Q., Hou, Z., Liao, J., Fu, L. and Peng, Q., 2016. Influences of the land use pattern on water quality in loworder streams of the Dongjiang River basin, China: a multi-scale analysis. Science of the total environment, 551, pp.205-216.

Duan, W., He, B., Nover, D., Yang, G., Chen, W., Meng, H., Zou, S. and Liu, C., 2016. Water quality assessment and pollution source identification of the eastern Poyang Lake Basin using multivariate statistical methods. Sustainability, 8(2), p.133.

Effendi, H., 2016. River water quality preliminary rapid assessment using pollution index. Procedia Environmental Sciences, 33, pp.562-567.

Effendi, H. and Wardiatno, Y., 2015. Water quality status of Ciambulawung River, Banten Province, based on pollution index and NSF-WQI. Procedia Environmental Sciences, 24, pp.228-237.

Fallah, M. and Zamani-Ahmadmahmoodi, R., 2017. Assessment of water quality in Iran's Anzali Wetland, using qualitative indices from 1985, 2007, and 2014. Wetlands ecology and management, 25(5), pp.597-605.

Geissen, V., Mol, H., Klumpp, E., Umlauf, G., Nadal, M., van der Ploeg, M., van de Zee, S.E. and Ritsema, C.J., 2015. Emerging pollutants in the environment: a challenge for water resource management. International Soil and Water Conservation Research, 3(1), pp.57-65.

Geng, L.K., 2017. A GIS-Based Water Quality Assessment and Pollution Control Planning Approach for Lake Management (WQAPCP) (Doctoral dissertation, Concordia University).

Gissi, F., Stauber, J.L., Binet, M.T., Golding, L.A., Adams, M.S., Schlekat, C.E., Garman, E.R. and Jolley, D.F., 2016. A review of nickel toxicity to marine and estuarine tropical biota with particular reference to the South East Asian and Melanesian region. Environmental pollution, 218, pp.1308-1323.

Gitau, M.W., Chen, J. and Ma, Z., 2016. Water quality indices as tools for decision making and management. Water resources management, 30(8), pp.2591-2610.

Hariyanto, T., Pribadi, C.B., Kurniawan, A., Sukojo, B.M., Taufik, M. and Indeswari, L., 2018, August. Analysis of Concentration of Total Suspended Solid (TSS) in PorongSidoarjo River Waters. In 2018 4th International Conference on Science and Technology (ICST) (Vol. 1, pp. 1-5). IEEE.

Hoseinzadeh, E., Khorsandi, H., Wei, C. and Alipour, M., 2015. Evaluation of Aydughmush river water quality using the national sanitation foundation water quality index (NSFWQI), river pollution index (RPI), and forestry water quality index (FWQI). Desalination and Water Treatment, 54(11), pp.2994-3002.

Hutchins, M.G., Abesser, C., Prudhomme, C., Elliott, J.A., Bloomfield, J.P., Mansour, M.M. and Hitt, O.E., 2018. Combined impacts of future land-use and climate stressors on water resources and quality in groundwater and surface waterbodies of the upper Thames river basin, UK. Science of the Total Environment, 631, pp.962-986.

Jha, D.K., Devi, M.P., Vidyalakshmi, R., Brindha, B., Vinithkumar, N.V. and Kirubagaran, R., 2015. Water quality assessment using water quality index and geographical information system methods in the coastal waters of Andaman Sea, India. Marine pollution bulletin, 100(1), pp.555-561.

Jonah, C., Maitho, T. and Omware, Q., 2015. Water access and sustainable rural livelihoods: a case of elementaita Division in Nakuru County, Kenya. International Journal of Science, Technology and Society, 3(1), pp.9-23.

Kachroud, M., Trolard, F., Kefi, M., Jebari, S. and Bourrié, G., 2019. Water Quality Indices: Challenges and Application Limits in the Literature. Water, 11(2), p.361.

Kafrawy, S.B.E., Donia, N.S. and Mohamed, A.M., 2017. Water quality assessment based on CWQI and NDWI indices in Mariout Lake, Egypt. MOJ Eco Environ Sci, 2(5), p.00039. 
Krishan, G., Singh, S., Singh, R.P., Ghosh, N.C. and Khanna, A., 2016. Water quality index of groundwater in Haridwar district, Uttarakhand, India. Water Energy Int, 58(10), pp.55-58.

Kumpel, E. and Nelson, K.L., 2016. Intermittent water supply: prevalence, practice, and microbial water quality. Environmental science \& technology, 50(2), pp.542-553.

Li, C., Sun, L., Jia, J., Cai, Y. and Wang, X., 2016. Risk assessment of water pollution sources based on an integrated k-means clustering and set pair analysis method in the region of Shiyan, China. Science of the Total Environment, 557, pp.307-316.

Liu, Z.H., 2018. Deriving applicable ammonia water quality criteria for Liao River China (No. Ph. D). Deakin University.

Liu, Y., Liang, Y., Liu, S., Rosenblum, D.S. and Zheng, Y., 2016. Predicting urban water quality with ubiquitous data. arXiv preprint arXiv:1610.09462.

Lu, Y., Song, S., Wang, R., Liu, Z., Meng, J., Sweetman, A.J., Jenkins, A., Ferrier, R.C., Li, H., Luo, W. and Wang, T., 2015. Impacts of soil and water pollution on food safety and health risks in China. Environment international, 77, pp.5-15.

Malsy, M., Flörke, M. and Borchardt, D., 2017. What drives the water quality changes in the Selenga Basin: climate change or socioeconomic development?. Regional environmental change, 17(7), pp.1977-1989.

Marani-Barzani, M., Eslamian, S., Dehghan, S., Singh, V.P. and Salleh, K.B.O., 2018. A spatial vulnerability analysis of multi-hazard threat in Zayandeh-Roud basin in Isfahan, Isfahan province, Iran. Journal of Environmental Chemistry and Toxicology, 2(1).

Merrill, N.H., Mulvaney, K.K., Martin, D.M., Chintala, M.M., Berry, W., Gleason, T.R., Balogh, S. and Humphries, A.T., 2018. A Resilience Framework for Chronic Exposures: Water Quality and Ecosystem Services in Coastal Social-Ecological Systems. Coastal management, 46(4), pp.242-258. Keiser, D.A. and Shapiro, J.S., 2018. Consequences of the Clean Water Act and the demand for water quality. The Quarterly Journal of Economics, 134(1), pp.349-396.

Misaghi, F., Delgosha, F., Razzaghmanesh, M. and Myers, B., 2017. Introducing a water quality index for assessing water for irrigation purposes: A case study of the Ghezel Ozan River. Science of the Total Environment, 589, pp.107-116.

Mohapatra, R.K. and Panda, C.R., 2017. Spatiotemporal variation of water quality and assessment of pollution potential in Paradip port due to port activities.

Mohseni-bandpey, A., Majlessi, M. and Kazempour, A., 2017. Evaluation of Golgol river water quality in Ilam province based on the National Sanitation Foundation Water Quality Index (NSFWQI). Journal of Health in the field, 1(4).

Naubi, I., Zardari, N.H., Shirazi, S.M., Ibrahim, N.F.B. and Baloo, L., 2016. Effectiveness of Water Quality Index for Monitoring Malaysian River Water Quality. Polish Journal of Environmental Studies, 25(1).

Noorka, I.R. and Heslop-Harrison, J.S., 2015. Agriculture and climate change in Southeast Asia and the Middle East: breeding, climate change adaptation, agronomy, and water security. Handbook of Climate Change Adaptation, pp.1511-1519.

Noori, R., Berndtsson, R., Hosseinzadeh, M., Adamowski, J.F. and Abyaneh, M.R., 2019. A critical review on the application of the National Sanitation Foundation Water Quality Index. Environmental pollution, 244, pp.575-587.

Pati, R.C. and Rout, S.P., 2018. Water Quality Status of Rushikulya River Basin, Odisha, India. Asian Journal of Research in Chemistry, 11(2), pp.221-231.

Piccolroaz, S., Calamita, E., Majone, B., Gallice, A., Siviglia, A. and Toffolon, M., 2016. Prediction of river water temperature: a comparison between a new family of hybrid models and statistical approaches. Hydrological Processes, 30(21), pp.3901-3917.

Pollard, D., DeConto, R.M. and Alley, R.B., 2015. Potential Antarctic Ice Sheet retreat driven by hydrofracturing and ice cliff failure. Earth and Planetary Science Letters, 412, pp.112-121.

Sicard, C., Glen, C., Aubie, B., Wallace, D., Jahanshahi-Anbuhi, S., Pennings, K., Daigger, G.T., Pelton, R., Brennan, J.D. and Filipe, C.D., 2015. Tools for water quality monitoring and mapping using paper-based sensors and cell phones. Water research, 70 , pp.360-369.

Suratman, S., Sailan, M.M., Hee, Y.Y., Bedurus, E.A. and Latif, M.T., 2015. A preliminary study of water quality index in Terengganu River basin, Malaysia. Sains Malaysiana, 44(1), pp.67-73.

Talalaj, I.A. and Biedka, P., 2016. Use of the landfill water pollution index (LWPI) for groundwater quality assessment near the landfill sites. Environmental science and pollution research, 23(24), pp.24601-24613.

Terry, J.A., Sadeghian, A., Baulch, H.M., Chapra, S.C. and Lindenschmidt, K.E., 2018. Challenges of modelling water quality in a shallow prairie lake with seasonal ice cover. Ecological modelling, 384, pp.43-52.

Ullah, H., Noreen, S., Rehman, A., Waseem, A., Zubair, S., Adnan, M. and Ahmad, I., 2017. Comparative study of heavy metals content in cosmetic products of different countries marketed in Khyber Pakhtunkhwa, Pakistan. Arabian Journal of Chemistry, 10(1), pp.10-18.

Van Vuuren, D.P., Stehfest, E., Gernaat, D.E., Doelman, J.C., Van den Berg, M., Harmsen, M., de Boer, H.S., Bouwman, L.F., Daioglou, V., Edelenbosch, O.Y. and Girod, B., 2017. Energy, land-use and greenhouse gas emissions trajectories under a green growth paradigm. Global Environmental Change, 42, pp.237-250.

Wahid, A.K.A., Ghdhban, I.I. and Salih, R.A., 2018. Evaluation of a Number of Water Treatment Plants in Kirkuk Governorate using the Water Quality Index. Tikrit Journal of Engineering Sciences, 25(1), pp.49-59.

Wan, L., Cai, W., Jiang, Y. and Wang, C., 2016. Impacts on quality-induced water scarcity: drivers of nitrogen-related water pollution transfer under globalization from 1995 to 2009. Environmental Research Letters, 11(7), p.074017.

Wu, Z., Wang, X., Chen, Y., Cai, Y. and Deng, J., 2018. Assessing river water quality using water quality index in Lake Taihu Basin, China. Science of the Total Environment, 612, pp.914-922.

Zhang, Y., Chu, C., Li, T., Xu, S., Liu, L. and Ju, M., 2017. A water quality management strategy for regionally protected water through health risk assessment and spatial distribution of heavy metal pollution in 3 marine reserves. Science of The Total Environment, 599, pp.721-731.

Zhou, Y., Ma, J., Zhang, Y., Qin, B., Jeppesen, E., Shi, K., Brookes, J.D., Spencer, R.G., Zhu, G. and Gao, G., 2017. Improving water quality in China: Environmental investment pays dividends. Water research, 118, pp.152-159.

\section{Citation:}

Safieh, J., Rebwar, D., Hamed, M. H., Saeed, M. A. H., Forough, J. (2020). Investigation of water quality in wet and dry seasons under climate change. Ukrainian Journal of Ecology, 10(5), 94-104. 